\title{
The Experimental Gamma Radiation Dose Rate for Radiation Hazard into Adhesive Building Materials in Saudi Arabia
}

\author{
Humood Alshammari ${ }^{*}$, A. Algammidi ${ }^{1}$, Ahmed Algammidi $^{2}$ \\ ${ }^{1}$ King Abdualziz City for Science and Technology, Riyadh, Saudi Arabia \\ ${ }^{2}$ Department of Chemistry, King Saud University, Riyadh, Saudi Arabia \\ Email: ^hshamari@kacst.edu.sa
}

How to cite this paper: Alshammari, H., Algammidi, A. and Algammidi, A. (2017) The Experimental Gamma Radiation Dose Rate for Radiation Hazard into Adhesive Building Materials in Saudi Arabia. Open Journal of Radiology, 7, 272-291. https://doi.org/10.4236/ojrad.2017.74030

Received: October 12, 2017

Accepted: December 23, 2017

Published: December 26, 2017

Copyright ( 2017 by authors and Scientific Research Publishing Inc. This work is licensed under the Creative Commons Attribution International License (CC BY 4.0).

http://creativecommons.org/licenses/by/4.0/

\begin{abstract}
The primary aim of this work was clearly to apply the norms of radiation protection to building residents against natural radioactivity. This was done through measurement of natural radioactivity in adhesive building materials using HPGe gamma ray spectrometer. The radium equivalent activity $\left(R a_{e q}\right)$, indoor gamma absorbed dose rate $\left(D_{R}\right)$, and annual effective dose $\left(H_{R}\right)$ associated with natural radioactivity were computed to assess the radiation hazards in adhesive building materials. The obtained specific activities of these natural radionuclides and the calculated radiation hazard indexes were compared with the international recommended values. The findings in this work of natural radioactivity levels were below the acceptable limits. Therefore, it was found the adhesive building materials were safe to be used as construction materials. Also, as a minor work, previous unpublished data of heavy metals in the same study adhesive materials were investigated by ICP-MS to figure out the correlation between heavy metal presence and natural radioactivity. The findings showed insignificant correlations between heavy metals and radioactivity.
\end{abstract}

\section{Keywords}

Building Material, Radioactivity, Adhesives

\section{Introduction}

The exposure of human to naturally occurring radiation comes primarily from two different origins. The first source, the main contributor is the terrestrial radioactive materials which shape from the formation of the earth crust. The 
second source comes directly from the cosmic radiation. The term of naturally occurring radionuclides is known as NORM. Only long-lived radionuclides, with half-lives comparable to the age of the earth, and their daughters, contribute to this natural radiation background in significant levels [1].

The majority of NORMs belong to the U-238, Th-232 decay series and K-40 as illustrated in Figure 1. NORMs emit alpha, beta particles and gamma ray as these radiations represent the primary sources of external exposure to the society [2].

These radionuclides (U-238, Th-232 decay series, and K-40) which emit either beta or alpha particles may be ingested or inhaled and surely can increase the internal exposures. Moreover, some radiation emitters may emit gamma radiation following their nuclear decay [3].

Terrestrial radionuclides occurred in all types of building materials, can give rise to external exposures owing to gamma rays. The specific activities of the radionuclides of various rocks and soils used as raw material in building materials are presented in Table 1. In Table 1, ignition rocks show higher levels of natural radionulcides than sedimentary rocks.

There have been so many studies concerning NORMs in soils, rocks, and construction materials which can furnish invaluable details on the nature and levels of radiation in any region and provide information in the change in radionuclide concentrations. All the studies of regional radionuclides in Table 1 showed that most of building materials contain wide ranges of NORM levels.

There have been so many studies concerning NORMs in soils, rocks, and construction materials which can furnish invaluable details on the nature and levels of radiation in any region and provide information in the change in radionuclide concentrations. All the studies of regional radionuclides in Table 1 showed that most of building materials contain wide ranges of NORM levels.

Determination of radioactivity in building materials used in them, shows that natural radionuclides of uranium (U-238) and thorium (Th-232) series, together

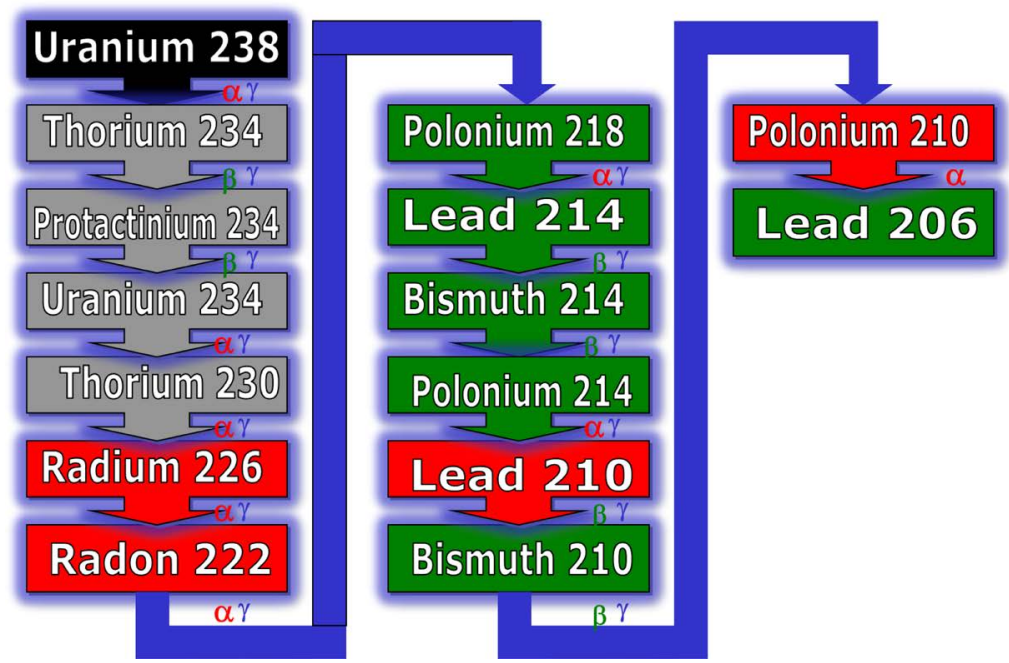

Figure 1. Uranium-238 decay series. 
Table 1. Typical activities of U-238, Th-232, and K-40 in rocks and soils, data cited from [3].

\begin{tabular}{|c|c|c|c|c|c|c|}
\hline \multirow{2}{*}{ Rock Type } & \multicolumn{2}{|c|}{ Potassium-40 } & \multicolumn{2}{|c|}{ Thorium-232 } & \multicolumn{2}{|c|}{ Uranium-238 } \\
\hline & Total K (\%) & $\mathrm{Bq} \cdot \mathrm{kg}^{-1}$ & ppm & $\mathrm{Bq} \cdot \mathrm{kg}^{-1}$ & ppm & $\mathrm{Bq} \cdot \mathrm{kg}^{-1}$ \\
\hline \multicolumn{7}{|l|}{ Igneous rocks } \\
\hline Crustal average & 0.8 & 300 & 3 to 4 & 10 to 15 & 0.5 to 1 & 7 to 10 \\
\hline Mafic & $0.3-1.1$ & $70-400$ & $1.6-2.7$ & 7 & $0.5-0.9$ & 7 \\
\hline Salic & 4.5 & $1100-1500$ & $16-20$ & 60 & $3.9-4.7$ & 50 \\
\hline Granite (crustal aver.) & $\leq 4$ & $\leq 1000$ & 17 & 70 & 3 & 40 \\
\hline \multicolumn{7}{|l|}{ Sedimentary rocks } \\
\hline Shale, sandstones & 2.7 & 800 & 12 & 50 & 3.7 & 40 \\
\hline Clean quartz & $\leq 1$ & $\leq 300$ & $\leq 2$ & $\leq 8$ & $\leq 1$ & $\leq 10$ \\
\hline Dirty quartz & 2 & 400 & 3 to 6 & 10 to 25 & 2 to 3 & 40 \\
\hline Arkose & 2 to 3 & $600-900$ & 2 & $\leq 8$ & 1 to 2 & 10 to 25 \\
\hline Beach sands & $\leq 1$ & $\leq 300$ & 6 & 25 & 3 & 40 \\
\hline Carbonate rocks & 0.3 & 70 & 2 & 8 & 2 & 25 \\
\hline All rock (range) & $0.3-4.5$ & $700-1500$ & $1.6-20$ & 7 to 80 & $0.5-4.7$ & 7 to 60 \\
\hline Continental crust (ave.) & 2.8 & 850 & 10.7 & 44 & 2.8 & 36 \\
\hline Soil (ave.) & 1.5 & 400 & 9 & 37 & 1.8 & 22 \\
\hline
\end{tabular}

with the radioactive isotope of potassium (K-40), are presented. Limits of Ra-226 concentrations are established by different countries in order to control Rn-222 levels $\left(200 \mathrm{~Bq} / \mathrm{m}^{3}\right.$ in European Union and up to $1000 \mathrm{~Bq} / \mathrm{m}^{3}$ in Saudi Arabia). Potassium-40 and others gamma emitters of Ra-226 and Th-232 descendants, can cause an external dose. In European Union, a maximum value of $1 \mathrm{mSv} \cdot \mathrm{y}^{-1}$ is recommended as well as in Saudi Arabia [4].

Merle Lust studied the NORM in building materials used in Estonia. During the Merle Lust investigation, 53 samples of commonly used raw materials and building products were collected and measured. The activity levels were determined by gamma ray spectrometry [5]. Their mean values were in the ranges 7 to $747 \mathrm{~Bq} / \mathrm{kg}$ for $\mathrm{K}-40,4.4$ to $69 \mathrm{~Bq} / \mathrm{kg}$ for $\mathrm{Ra}-226$, and 0.8 to $86 \mathrm{~Bq} / \mathrm{kg}$ for Th-232. The activity index $I$ in the 53 different building materials varied from 0.02 to 0.74 and the radium equivalent, from 6 to 239. The average annual dose for the people, caused by the building materials of dwellings, was assessed for most commonly used materials. It was estimated to be in the range from 0.16 $\mathrm{mSv}$ to $0.44 \mathrm{mSv}$.

Adriana Etokov and Lenka Palakov [6] studied activities of Ra-226, Th-232 and K-40 and radiological parameters (radium equivalent activity, gamma and alpha indexes, the absorbed gamma dose rate and external and internal hazard indices) of cements and cement composites commonly used in the Slovak Republic. The cement samples of 8 types of cements from Slovak cement plants 
and five types of composites made from cement type CEM I were analyzed. The radionuclide activities in the cements ranged from 8.58 to $19.1 \mathrm{~Bq} / \mathrm{kg}, 9.78$ to $26.3 \mathrm{~Bq} / \mathrm{kg}$ and 156.5 to $489.4 \mathrm{~Bq} / \mathrm{kg}$ for Ra-226, Th-232 and K-40, respectively. The radiological parameters in cement samples were calculated as follows: mean radium equivalent activity $R a_{e q}=67.87 \mathrm{~Bq} / \mathrm{kg}$, gamma index $I_{\gamma}=0.256$, alpha index $I_{\alpha}=0.067$, the absorbed gamma dose rate $D=60.76 \mathrm{nGy} / \mathrm{h}$, external hazard index $H_{e x}=0.182$ and internal hazard index $H_{i n}$ was 0.218 . The radionuclide activity in composites ranged from 6.84 to $10.8 \mathrm{~Bq} / \mathrm{kg}$ for Ra-226, 13.1 to $20.5 \mathrm{~Bq} / \mathrm{kg}$ for Th-232 and 250.4 to $494.4 \mathrm{~Bq} / \mathrm{kg}$ for K-40.

Singh [7] carried out radiation measurement of Indian building materials. The activity concentrations of Ra-226, Th-232 and K-40 have been determined by gamma-ray spectrometry. The measured activity in the selected building materials ranges from 3.2 to $151.7 \mathrm{~Bq} / \mathrm{kg}, 14$ to $63.7 \mathrm{~Bq} / \mathrm{kg}$ and 24.3 to $121.5 \mathrm{~Bq} / \mathrm{kg}$ for Ra-226, Th-232 and K-40 respectively. The activity concentration of U-238 were determined using fission track technique and the value ranges from 0.11 to 3.85 ppm.

W.R. Alharbi, J.H. AlZahrani [8] studied the radioactivity in some building materials in Saudi Arabia, the natural radionuclides (Ra-226, Th-232 and K-40) present in various building materials available in Saudi Arabia (Jeddah city) analyzed using Gamma-ray spectrometry. The results showed that the activity concentration of Ra-226, Th-232 and K-40 was between $12.6 \mathrm{~Bq} / \mathrm{kg}$ (Brick-clay) to $31.5 \mathrm{~Bq} / \mathrm{kg}$, (Granite), 9.2 Bq/kg (Brick-clay) to $27.2 \mathrm{~Bq} / \mathrm{kg}$ (Granite) and $114.4 \mathrm{~Bq} / \mathrm{kg}$ (Brick-clay) to $534.7 \mathrm{~Bq} / \mathrm{kg}$ (Granite), respectively. The radiological hazard parameters radium equivalent activity, gamma index, absorbed dose rate and the annual exposure rate, were calculated to assess the radiation hazards associated with Saudian buildings. All studied samples were lower than world average limits. The results were compared with the published data of other countries and with the world average limits. The measurements helped in the development of standards and guidelines for the use and management of building materials.

Therefore, this work dealt with assessing of natural radioactivity in adhesive materials used and sold in Riyadh city, Saudi Arabia.

\section{Assessment of Radiation Hazard}

The risk assessment of radiation doses can be given in form of radiation indexes. In literature, there has been tonnes of publications on how to evaluate the radiation hazards linked to presence of ${ }^{226} \mathrm{Ra},{ }^{238} \mathrm{U},{ }^{232} \mathrm{Th}$, and ${ }^{40} \mathrm{~K}$ [9] [10].

In order to carry on such assessment, one needs to provide some terminologies associated with radiation hazard. Therefore, this section will explain them.

\subsection{Absorbed Dose Rate}

The direct link between radioactivity levels and their exposure is known to be the absorbed dose rate. The following equation can be used to calculate the ab- 
sorbed dose rate [11] [12]:

$$
D=0.462 A_{\mathrm{Ra}-226}+0.604 A_{\mathrm{Th}-232}+0.0417 A_{\mathrm{K}-40}
$$

where $D$ is the adsorbed dose rate in $\mathrm{nGy} / \mathrm{h}$,

$A_{\mathrm{Ra}-226}, A_{\mathrm{Th}-232}$ and $A_{\mathrm{K}-40}$ are the activities of $\mathrm{Ra}_{226}, \mathrm{Th}_{232}$ and $\mathrm{K}_{40}$, respectively. The equation above was taken directly from UNSCEAR.

\subsection{Radium Equivalent Activity}

This index is very commonly used in radiological hazard evaluation. The index was mainly introduced by UNSCEAR owing to uniform distribution of the mentioned-above radionuclide in environmental, geochemical, biological samples [12] [13] [14].

The next equation can be estimated through:

$$
R a_{e q}=A_{\mathrm{Ra}-226}+1.43 A_{\mathrm{Th}-232}+0.077 A_{\mathrm{K}-40}
$$

where $A_{\mathrm{Ra}-226}, A_{\mathrm{Th}-232}$ and $A_{\mathrm{K}-40}$ are the activities levels of Ra-226, Th-232, and $\mathrm{K}-40$, respectively.

The value of $370 \mathrm{~Bq} / \mathrm{kg}$ is set to be permissible max level that corresponds to effective dose of $1 \mathrm{mSv}$ for public [15] [16].

\subsection{Annual Effective Dose Equivalent}

It is well known that the absorbed dose rate in one meter in air above the earth surface can not provide the radiological risk to public [17]. So, the absorbed dose has be to converted to annual effective dose equivalent (AEDE) from outdoor regional gamma radiation. In order to calculate the annual effective dose equivalent, one can use the following equation [18]:

$$
\mathrm{AEDE}=D(\mathrm{nGy} / \mathrm{h}) \times 8760 \mathrm{hr} \times 0.2 \times 0.7(\mathrm{~Sv} / \mathrm{Gy}) \times 10^{-3}
$$

where $D$ is absorbed dose,

$0.7(\mathrm{~Sv} / \mathrm{Gy})$ is conversion factor,

0.2 is outdoor occupancy factor.

\subsection{External Hazard Index}

Krieger proposed a model to introduce external hazard index $\left(H_{e x}\right)$ owing to limitation of radiation attribute to natural radionuclide [19].

To calculate the external radiation hazard, one can use the following equation:

$$
H_{e x}=\left[\frac{A_{\mathrm{Ra}}}{370}\right]+\left[\frac{A_{\mathrm{Th}}}{259}\right]+\left[\frac{A_{\mathrm{K}}}{4810}\right] \leq 1
$$

The max value of $H_{e x}$ equal to unity meets to the upper limit of $R a_{e q} 370$ $\mathrm{Bq} / \mathrm{Kg} \mathrm{Kg}$ [20] [21].

\section{Measurements of Natural Radioactivity in Building Materials in Saudi Arabia}

The samples were crushed using crusher and then homogenized. The homoge- 
nized samples were filled into $1000 \mathrm{ml}$ Marinelli beakers which were later hermetically sealed with the help of PVC (polyvinyl chloride) commercial to prevent the escape of air-borne of Rn-222 and Rn-220 from the samples. All the samples were accurately weighted and stored for period of at least one month prior to determination in order to attain radioactive secular equilibrium between Ra-226 and Rn-222 [9].

In this investigation, the sample activities in building materials were measured by using high-resolution gamma-ray spectrometry system consists of coaxial hyper-pure germanium (HPGe) detector with highly passive shielding and low background. The detector was cooled with liquid nitrogen cryostat to re-duce the leakage current. To reduce the background radiation from natural sources the detector was enclosed of $10 \mathrm{~cm}$ thick cylindrical lead shield. The lead shielding was graded with an inner layer of thick copper to reduce any influence fluorescences [22].

The detector was connected to a pre-amplifier, shaping amplifier and high voltage power supply which were used for conversion of the observed energy into a pulse height spectrum. The pulse amplitude was converted to a discrete number through more 8000 channel multi-channel analyser (MCA). The data acquisition, display, and analysis of $\gamma$ spectra were carried out using Genie 2000 software [23].

The relationship between the channel numbers corresponding to absolute yenergies was determined. The specification of the used instrument is listed in Table 2 [22].

In this work, gamma reference sources containing mixed of radionuclide were used for energy set of calibration. These references emit a wide range of gammaray energies covering the entire energy range of interest. The main gamma-ray energy lines of the used references are shown in Table 3.

The gamma energies used for Ra-226 was at $186.2 \mathrm{keV}$ and $\mathrm{Pb}-214$ was also used at different energies at 295.2 and $351.9 \mathrm{keV}$.

For gamma-ray spectrometry of unknown, the detector efficiency measurement plays important role in gamma-counting. The full-energy peak efficiency

Table 2. The HPGe specifications.

\begin{tabular}{cc}
\hline Geomertry & Co-axial open end closed end faceing window \\
\hline Diameter & $74.7 \mathrm{~mm}$ \\
Length & $92.9 \mathrm{~mm}$ \\
Active area window & $11.6 \mathrm{~mm}$ \\
Operating Voltage & $4500 \mathrm{~V}$ \\
Leakage Current & $0.01 \mathrm{~A}$ \\
Amplifier gain & 50 \\
Amplifier fine & $30-40$ \\
Pulse time & 6 micro sec
\end{tabular}


Table 3. Gamma energies [22].

\begin{tabular}{|c|c|c|c|}
\hline $\begin{array}{l}\text { Identified } \\
\text { radionuclide }\end{array}$ & $\begin{array}{c}\text { Gamma-ray } \\
\text { energy (KeV) }\end{array}$ & $\begin{array}{c}\text { Gamma emission } \\
\text { probability }\end{array}$ & $\begin{array}{l}\text { Source of gamma ray } \\
\text { transition }\end{array}$ \\
\hline Th-234 & 92.58 & $0.0558 \pm 0.0030$ & U-238 series-doublet peak \\
\hline Ac- 228 & 129.06 & $0.0242 \pm 0.0009$ & Th-232 series \\
\hline Ac- 228 & 153.97 & $0.0072 \pm 0.0002$ & Th-232 series \\
\hline U-235 & 185.72 & $0.572 \pm 0.0005$ & Primordial U-235 \\
\hline $\mathrm{Ra}-226$ & 186.21 & $0.0359 \pm 0.0019$ & U-238 series \\
\hline Ac- 228 & 209.25 & $0.0389 \pm 0.0007$ & Th-232 series \\
\hline $\mathrm{Pb}-212$ & 238.63 & $0.4360 \pm 0.0030$ & Th-232 series \\
\hline $\mathrm{Pb}-214$ & 241.99 & $0.0725 \pm 0.0002$ & Th-238 series \\
\hline Ac- 228 & 270.24 & $0.0346 \pm 0.0006$ & Th-232 series \\
\hline Tl-208 & 277.35 & $0.0227 \pm 0.0003$ & Th-232 series \\
\hline $\mathrm{Pb}-214$ & 295.22 & $0.1842 \pm 0.0004$ & Th-238 series \\
\hline $\mathrm{Pb}-214$ & 300.08 & $0.0318 \pm 0.0013$ & Th-232 series \\
\hline Ac- 228 & 328 & $0.0295 \pm 0.0012$ & Th-232 series \\
\hline Ac-229 & 338.32 & $0.1127 \pm 0.0019$ & Th-232 series \\
\hline $\mathrm{Pb}-214$ & 351.93 & $0.3560 \pm 0.0007$ & Th-238 series \\
\hline Ac- 228 & 463 & $0.0440 \pm 0.0007$ & Th-232 series \\
\hline Annihilation & 511 & & Annihilation radiation \\
\hline $\mathrm{Tl}-208$ & 583.19 & $0.3055 \pm 0.0017$ & Th-232 series \\
\hline $\mathrm{Bi}-214$ & 609.31 & $0.4549 \pm 0.0016$ & U-238 series \\
\hline Cs-137 & 661.65 & $0.8510 \pm 0.0020$ & Man-made \\
\hline $\mathrm{Bi}-212$ & 727.33 & $0.0674 \pm 0.0012$ & Th-232 series \\
\hline $\mathrm{Bi}-214$ & 768.35 & $0.0489 \pm 0.0001$ & U-238 series \\
\hline Ac- 228 & 794.94 & $0.0425 \pm 0.0007$ & Th-232 series \\
\hline Tl-208 & 860.56 & $0.0448 \pm 0.0004$ & Th-232 series \\
\hline Ac- 228 & 911.2 & $0.2580 \pm 0.0040$ & Th-232 series \\
\hline $\mathrm{Bi}-214$ & 934.06 & $0.0311 \pm 0.0001$ & U-238 series \\
\hline Ac- 228 & 964.76 & $0.0499 \pm 0.0002$ & Th-232 series \\
\hline Ac- 228 & 968.97 & $0.1580 \pm 0.0030$ & Th-232 series \\
\hline $\mathrm{Bi}-214$ & 1120.28 & $0.1492 \pm 0.0003$ & U-238 series \\
\hline $\mathrm{Bi}-214$ & 1238.11 & $0.0583 \pm 0.0015$ & U-238 series \\
\hline $\mathrm{Bi}-214$ & 1377.67 & $0.0399 \pm 0.0001$ & U-238 series \\
\hline $\mathrm{Bi}-214$ & 1407.98 & $0.0239 \pm 0.001$ & U-238 series \\
\hline $\mathrm{K}-40$ & 1460.83 & $0.1066 \pm 0.0013$ & Primordial K-40 \\
\hline Ac- 228 & 1588.19 & $0.0322 \pm 0.0008$ & Th-232 series \\
\hline $\mathrm{Bi}-212$ & 1620.5 & $0.0151 \pm 0.0003$ & Th-232 series \\
\hline $\mathrm{Bi}-214$ & 1729.59 & $0.0298 \pm 0.0001$ & U-238 series \\
\hline $\mathrm{Bi}-214$ & 1764.49 & $0.1530 \pm 0.0003$ & U-238 series \\
\hline $\mathrm{Bi}-214$ & 2204.21 & $0.0492 \pm 0.0002$ & U-238 series \\
\hline Tl-208 & 2614.5 & $0.3585 \pm 0.0007$ & Th-232 series \\
\hline
\end{tabular}


can be computed through:

$$
\varepsilon_{f}=\frac{N_{p}}{N_{\gamma}}
$$

where $\varepsilon_{f}$ is defined as the full-energy peak efficiency,

$N_{p}$ is the net gamma-ray counting rate in the full-energy peak

$N_{\gamma}$ is defined as the gamma-ray emission rate where it can be calculated via:

$$
N_{\gamma}=A P_{\gamma}
$$

where $A$ is the activity in $\mathrm{Bq}$ of the reference and $P_{\gamma}$ is the branching ratio of the radionuclide.

In order to removed interference between multi peaks, the calibration of energy efficiency was carried out carefully. For every source, the energy efficiency was calculated using formula (5) as shown in Figure 2 and the energy channels was calculated as shown in Figure 3 [21] [22].

The minimum detection activity (MDA) which is the performance of gammaray spectrometry is defined as the lowest quantity of radionuclide that can be measured for a certain measurement. MDA can be calculated via the following

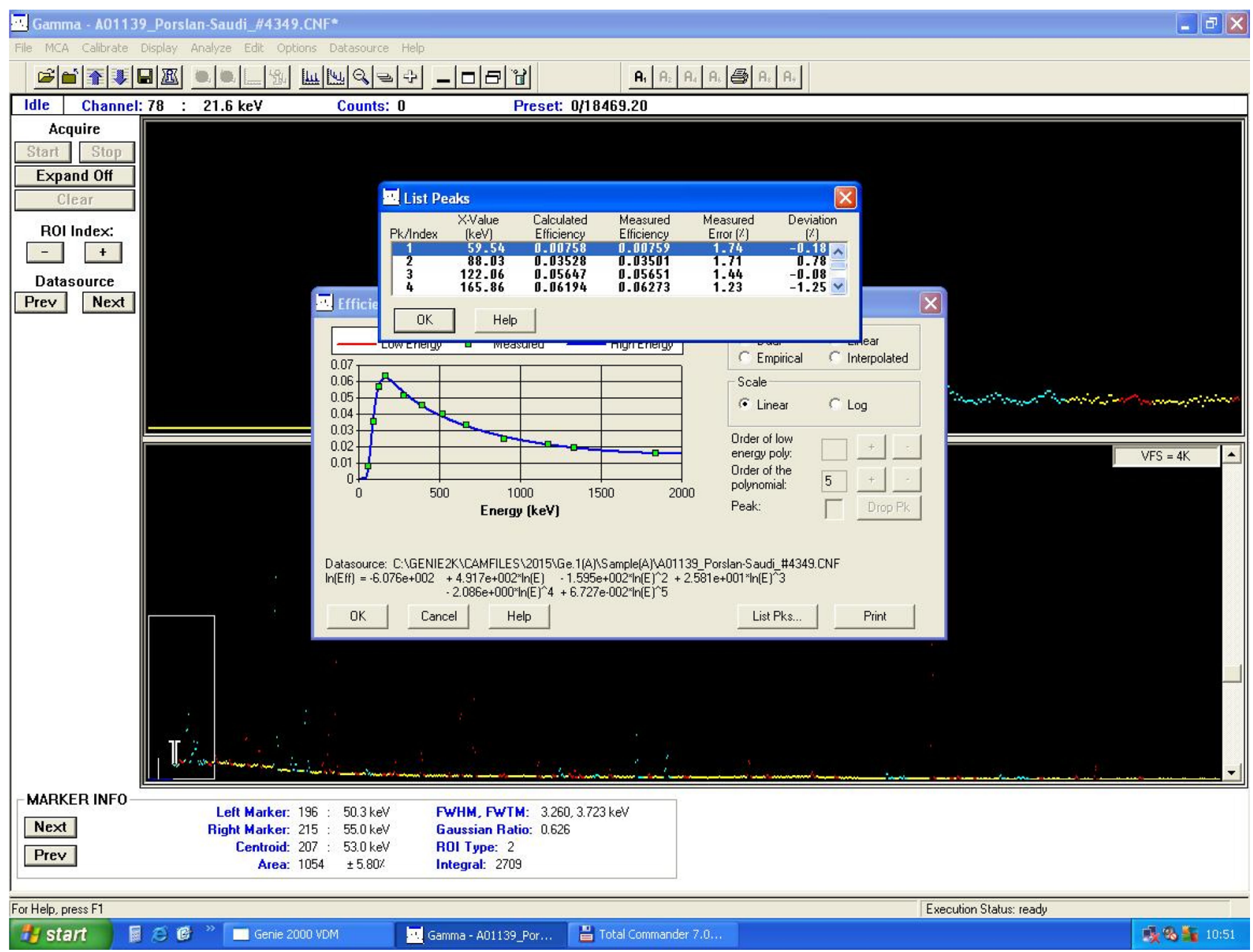

Figure 2. Absolute full-energy peak efficiency as function of $\gamma$ energy for the HPGe detector used in our study. 


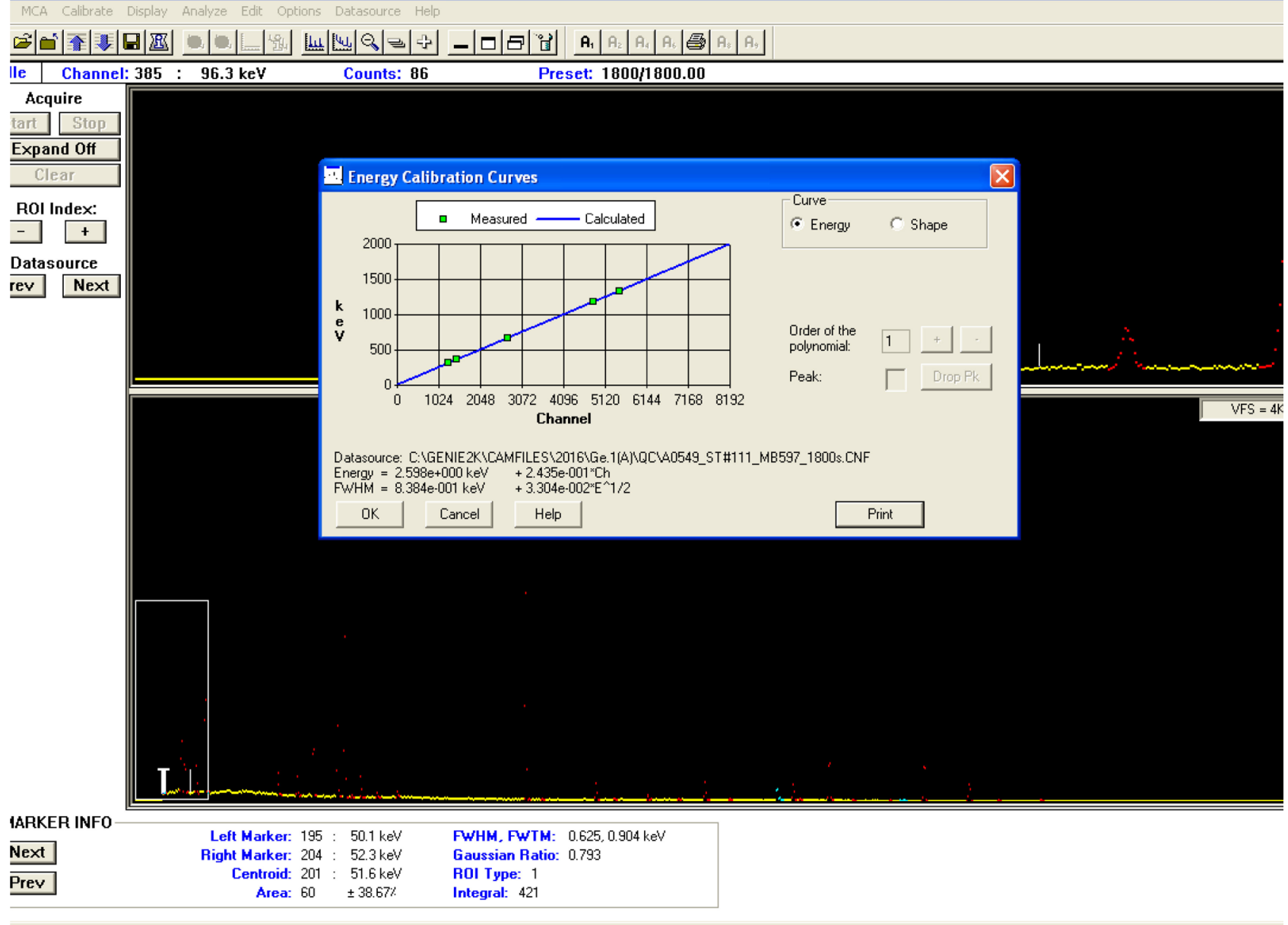

telp. press F1

Execution Status: ready

Figure 3. The relationship between gamma-ray energies and their channel number.

equation in unit of $\mathrm{Bq} / \mathrm{kg}$ :

$$
M D A=\frac{L_{D}}{\varepsilon_{f} P_{\gamma} T M}
$$

where $L_{D}$ is the detection limit,

$\varepsilon_{f}$ is the absolute efficiency of the detector,

$P_{\gamma}$ is the gamma branching ratio or gamma probability,

$T$ is the counting time,

$M$ is the sample mass in $\mathrm{kg}$.

$L_{D}$ can be expressed through the equation:

$$
\left.L_{D}=2.71+4.65 \text { (background }\right)^{0.5}
$$

$L_{D}$ was measured for over $170,000 \mathrm{sec}$ with no radiation and it was carried out with 1000 Marinelli beaker filled with tri-di-ionized water placed inside the detector using the same geometry.

The specific activity is defined as the activity per mass unit. The specific activity of individual radionuclide in the studied building material can be calculated using the following equation: 


$$
A=\frac{N}{\varepsilon_{f} P_{\gamma} T M K}
$$

where $\varepsilon_{f}$ is the efficiency of energy at the photopeak of interested radionuclide

$T$ is counting time in second $(86,400 \mathrm{sec})$

$M$ is the mass in $\mathrm{kg}$ of the analysed sample,

$P_{\gamma}$ is the gamma branching ratio or gamma probability,

$K$ is a correction factor,

$N$ is the corrected net peak area

$$
N=N_{S}-N_{B}
$$

where $N_{S}$ is the net peak area and $N_{B}$ is the net peak area of the background [23].

\section{Radiation Hazard in Adhesive Materials}

The relevant radiological assessed values for adhesive materials are listed in $\mathrm{Ta}$ ble 4 . The highest reported value of U-238 in adhesive was $17.4 \mathrm{~Bq} / \mathrm{kg}$ whereas the lowest value was $5.2 \mathrm{~Bq} / \mathrm{kg}$ and the mean value was $8.7 \mathrm{~Bq} / \mathrm{kg}$. For Th-232, the lowest reported value in this study was $5.3 \mathrm{~Bq} / \mathrm{kg}$ and the highest value was 12.4 Bq/kg. The average of Th-232, by this study, was $7.2 \mathrm{~Bq} / \mathrm{kg}$. For $\mathrm{K}-40$, The highest reported value, by our study, was $183 \mathrm{~Bq} / \mathrm{kg}$ and the lowest values was 0 $\mathrm{Bq} / \mathrm{kg}$ which is normal as adhesive does not contain potassium.

To discuss the statistical evaluation, one can start with confidence limits test of Shawhart. The confidence limit test of Th-232 in Figure 4 indicated that Th-232 levels in adhesive materials were normal distributed and all the data were located within the max and min border of confidence limits.

The confidence limit test for U-238 is illustrated in Figure 5. The U-238 levels clearly proved that data can be treated as parametric due to normal distribution of the obtained data.

The shawhart confidence limit interval test showed K- 40 results passed the test as illustrated in Figure 6.

$R a_{e q}$ mean value was $24 \mathrm{~Bq} / \mathrm{kg}$ that is lower than set limit of $370 \mathrm{~Bq} / \mathrm{kg}$ [24]. For $H_{e x}$, the lowest reported value was 0.05 and the highest value was 0.07 with mean value of $0.06 \mathrm{mSv} / \mathrm{yr}$. The fixed limit of $H_{e x}$ is set to be $1 \mathrm{mSv} / \mathrm{yr}$. $H_{\text {in }}$ lowest value for adhesive was $0.08 \mathrm{mSv} / \mathrm{yr}$ and highest value was $0.13 \mathrm{mSv} / \mathrm{yr}$ with mean of $0.09 \mathrm{mSv} / \mathrm{yr}$. Lucky, the study adhesive materials were less than max permissible value of $1 \mathrm{mSv} / \mathrm{yr}$. The annual effective does reported in this work was $0.08 \mathrm{mSv} / \mathrm{kg}$ in average where this values is less than max permissible value of $1 \mathrm{mSv} / \mathrm{yr}$. Therefore, The reported radiological values were far below the permissible limits. Therefore, it is obvious that the adhesive did not posses any radiation hazard to residents.

Turhan, eref et al. (2008) reported natural radioactivity in adhesive materials. In their study, U-238 activities were 7.3 to $69.4 \mathrm{~Bq} / \mathrm{kg}$ whereas this study showed the ranges were 0 to $17 \mathrm{~Bq} / \mathrm{kg}$. Thus, the study adhesives were located within the worldwide ranges. In Tuhan study, Th-232 activity was 2 to $57 \mathrm{~Bq} / \mathrm{kg}$ in adhesives 
Table 4. Radiation calculations for adhesive materials.

\begin{tabular}{|c|c|c|c|c|c|c|c|c|c|c|c|}
\hline Sample code & $\begin{array}{l}\mathrm{K}-40 \\
\mathrm{~Bq} \backslash \mathrm{Kg}\end{array}$ & $\begin{array}{r}\mathrm{Ra}-226 \\
\mathrm{~Bq} \backslash \mathrm{Kg}\end{array}$ & $\begin{array}{l}\text { Th-232 } \\
\mathrm{Bq} \backslash \mathrm{Kg}\end{array}$ & $\begin{array}{l}\mathrm{U}-238 \\
\mathrm{~Bq} \backslash \mathrm{Kg}\end{array}$ & $\mathrm{Ra}$ eq & $H_{e x} \leq 1$ & $H_{\text {in }} \leq 1$ & $\begin{array}{c}\alpha \\
\text { Concentration }\end{array}$ & $\begin{array}{c}\alpha \\
\text { index }\end{array}$ & $\begin{array}{l}\text { Outdoor } \\
\text { dose }\end{array}$ & $\begin{array}{c}\text { Annual } \\
\text { Effective } \\
\text { Dose }(\mathrm{mSv} / \mathrm{y})\end{array}$ \\
\hline A01129 & 49.22 & 14.11 & 6.24 & 15.76 & 26.82 & 0.07 & 0.11 & 0.09 & 0.07 & 12.45 & 0.09 \\
\hline A01121 & 0.00 & 12.20 & 12.40 & 15.80 & 29.93 & 0.08 & 0.11 & 0.10 & 0.06 & 13.34 & 0.09 \\
\hline A01140 & 93 & 8.1 & 6.8 & 8.7 & 24.99 & 0.07 & 0.09 & 0.09 & 0.04 & 11.84 & 0.08 \\
\hline A01144 & 183 & 11.4 & 7.1 & 0 & 35.64 & 0.10 & 0.13 & 0.13 & 0.06 & 17.31 & 0.12 \\
\hline B01047 & 13.7 & 9.6 & 6.4 & 6.9 & 19.81 & 0.05 & 0.08 & 0.07 & 0.05 & 8.98 & 0.06 \\
\hline B01057 & 40 & 9.6 & 6.4 & 4.06 & 21.83 & 0.06 & 0.08 & 0.08 & 0.05 & 10.08 & 0.07 \\
\hline $\mathrm{C} 0533$ & 12.3 & 9.89 & 9.61 & 9.29 & 24.58 & 0.07 & 0.09 & 0.09 & 0.05 & 11.05 & 0.08 \\
\hline B01059 & 81.8 & 7.6 & 5.7 & 7.3 & 22.05 & 0.06 & 0.08 & 0.08 & 0.04 & 10.46 & 0.07 \\
\hline B01061 & 69.8 & 6.5 & 5.07 & 5.2 & 19.12 & 0.05 & 0.07 & 0.07 & 0.03 & 9.06 & 0.06 \\
\hline $\mathrm{C} 0543$ & 18.05 & 12.7 & 4.87 & 11.5 & 21.05 & 0.06 & 0.09 & 0.07 & 0.06 & 9.64 & 0.07 \\
\hline B01044 & 36.4 & 18.1 & 5.03 & 17.4 & 28.10 & 0.08 & 0.12 & 0.10 & 0.09 & 13.00 & 0.09 \\
\hline C0548 & 0 & 9.8 & 6.8 & 9.4 & 20 & 0.05 & 0.08 & 0.07 & 0.05 & 8.75 & 0.06 \\
\hline $\mathrm{C} 0554$ & 9.6 & 11.1 & 7.9 & 5.8 & 23 & 0.06 & 0.09 & 0.08 & 0.06 & 10.43 & 0.07 \\
\hline $\mathrm{C} 0555$ & 32 & 6.85 & 5.3 & 8.89 & 17 & 0.05 & 0.06 & 0.06 & 0.03 & 7.79 & 0.05 \\
\hline $\mathrm{C} 0558$ & 25.2 & 9.8 & 10.3 & 4.3 & 26 & 0.07 & 0.10 & 0.09 & 0.05 & 11.97 & 0.08 \\
\hline Count & 15 & 15 & 15 & 15 & 15 & 15.00 & 15.00 & 15.00 & 15.00 & 15.00 & 15.00 \\
\hline Mean & 44.3 & 10.49 & 7.1 & 8.69 & 24 & 0.06 & 0.09 & 0.09 & 0.05 & 11.08 & 0.08 \\
\hline Stdev & 47.9 & 3.00 & 2.2 & 4.83 & 5 & 0.01 & 0.02 & 0.02 & 0.02 & 2.38 & 0.02 \\
\hline Range & 183.0 & 11.60 & 7.5 & 17.40 & 19 & 0.05 & 0.06 & 0.07 & 0.06 & 9.52 & 0.07 \\
\hline Minimum & 0.0 & 6.50 & 4.9 & 0.00 & 16.89 & 0.05 & 0.06 & 0.06 & 0.03 & 7.79 & 0.05 \\
\hline $25^{\text {th }}$ Percentile (Q1) & 12.3 & 8.10 & 5.3 & 5.20 & 19.81 & 0.05 & 0.08 & 0.07 & 0.04 & 9.06 & 0.06 \\
\hline $\begin{array}{c}50^{\text {th }} \text { Percentile } \\
\text { (Median) }\end{array}$ & 32.0 & 9.80 & 6.4 & 8.70 & 23.14 & 0.06 & 0.09 & 0.08 & 0.05 & 10.46 & 0.07 \\
\hline $75^{\text {th }}$ Percentile (Q3) & 69.8 & 12.20 & 7.9 & 11.50 & 26.82 & 0.07 & 0.11 & 0.09 & 0.06 & 12.45 & 0.09 \\
\hline Maximum & 183.0 & 18.10 & 12.4 & 17.40 & 35.64 & 0.10 & 0.13 & 0.13 & 0.09 & 17.31 & 0.12 \\
\hline $95.0 \%$ CI Mean & 17.7 to 70.7 & 8.8 to 12.1 & $\begin{array}{l}5.8 \text { to } \\
8.2\end{array}$ & $\begin{array}{c}6.1 \text { to } \\
11.3\end{array}$ & $\begin{array}{c}21.3 \text { to } \\
26.7\end{array}$ & $\begin{array}{c}0.06 \text { to } \\
0.07\end{array}$ & $\begin{array}{c}0.08 \text { to } \\
0.1\end{array}$ & 0.07 to 0.1 & $\begin{array}{c}0.04 \text { to } \\
0.06\end{array}$ & $\begin{array}{c}9.7 \text { to } \\
12.4\end{array}$ & 0.07 to 0.08 \\
\hline 95.0\% CI Sigma & $\begin{array}{c}35.038 \text { to } \\
75.477\end{array}$ & 2.2 to 4.7 & $\begin{array}{c}1.6 \text { to } \\
3.4\end{array}$ & $\begin{array}{c}3.5 \text { to } \\
7.6\end{array}$ & $\begin{array}{c}3.6 \text { to } \\
7.7\end{array}$ & $\begin{array}{c}0.01 \text { to } \\
0.02\end{array}$ & $\begin{array}{c}0.01 \text { to } \\
0.03\end{array}$ & 0.01 to 0.03 & $\begin{array}{c}0.01 \text { to } \\
0.02\end{array}$ & 1.7 to 3.7 & 0.01 to 0.02 \\
\hline $\begin{array}{l}\text { Anderson-Darling } \\
\text { Normality Test }\end{array}$ & 0.9 & 0.41 & 0.8 & 0.36 & 0.26 & 0.26 & 0.34 & 0.41 & 0.41 & 0.37 & 0.37 \\
\hline p-value (A-D Test) & 0.014 & 0.30 & 0.02 & 0.41 & 0.65 & 0.65 & 0.44 & 0.30 & 0.30 & 0.37 & 0.37 \\
\hline Skewness & 1.9 & 1.08 & 1.36 & 0.35 & 0.87 & 0.86 & 0.48 & 1.27 & 1.08 & 1.18 & 1.18 \\
\hline p-value (Skewness) & 0.003 & 0.07 & 0.02 & 0.52 & 0.13 & 0.13 & 0.39 & 0.03 & 0.07 & 0.04 & 0.04 \\
\hline Kurtosis & 4.4 & 1.77 & 1.39 & -0.22 & 0.89 & 0.89 & -0.49 & 2.51 & 1.77 & 2.17 & 2.17 \\
\hline p-value (Kurtosis) & 0.012 & 0.14 & 0.20 & 1.00 & 0.34 & 0.34 & 0.76 & 0.07 & 0.14 & 0.09 & 0.09 \\
\hline
\end{tabular}




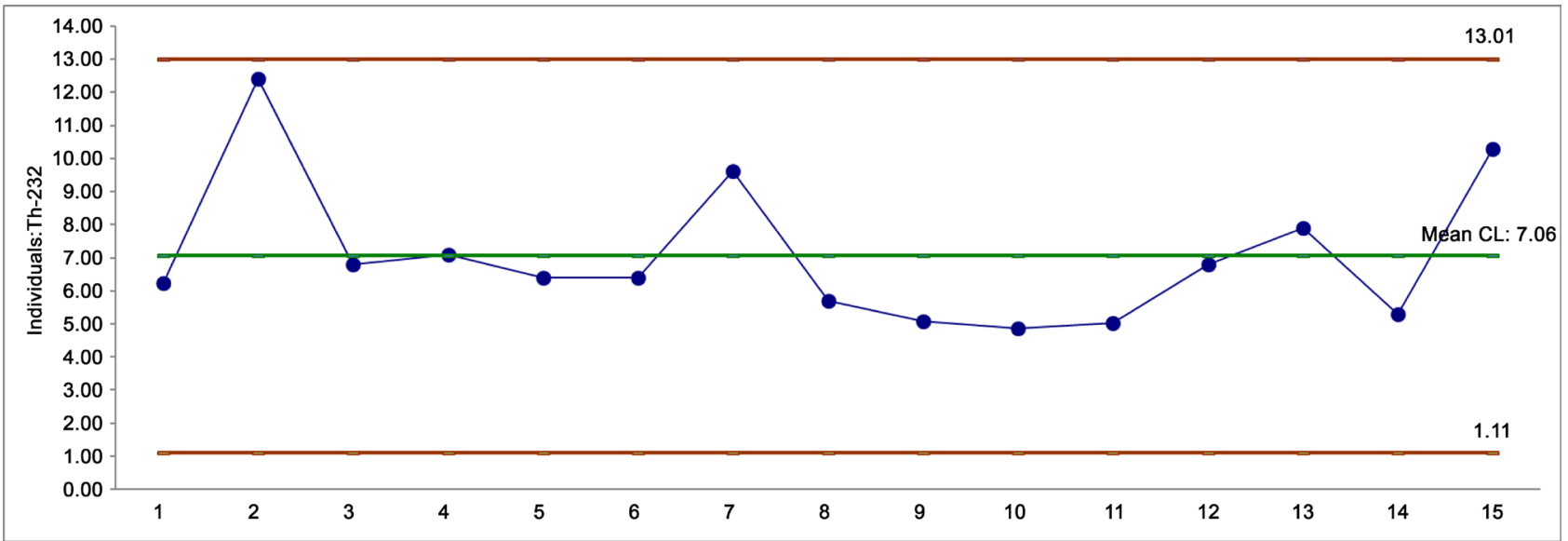

Figure 4. The Shawhart confidence limits of Th-232.

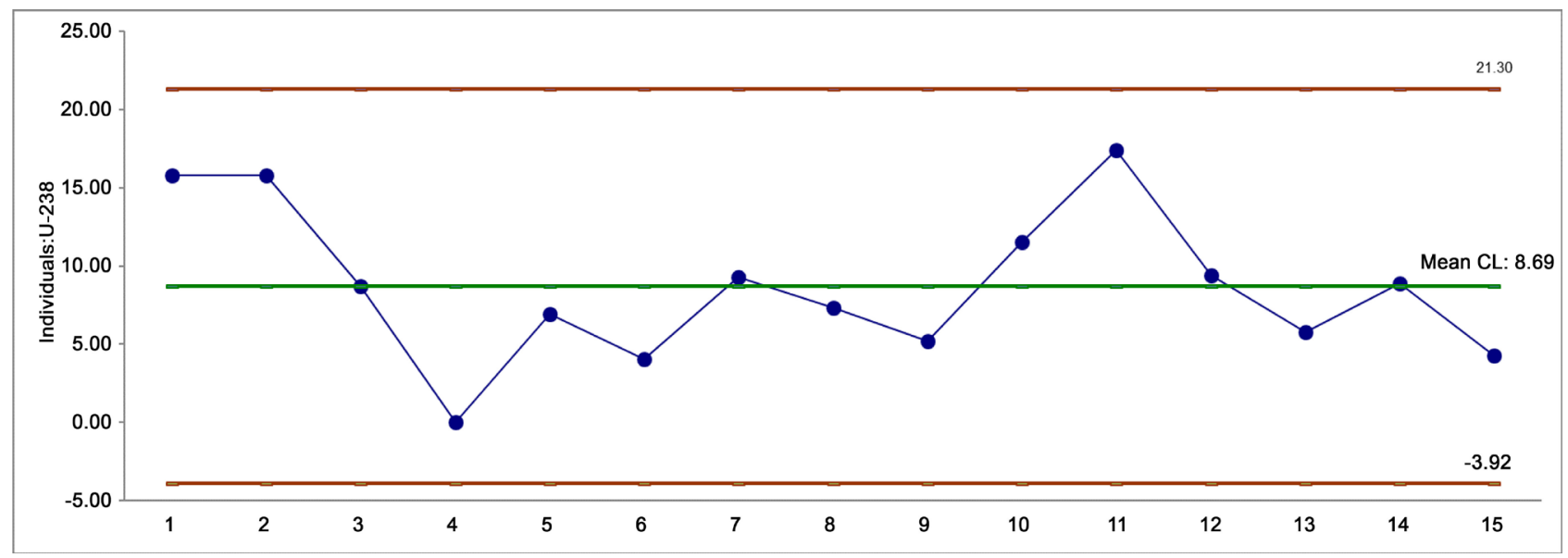

Figure 5. The Shawhart confidence limits of U-238.

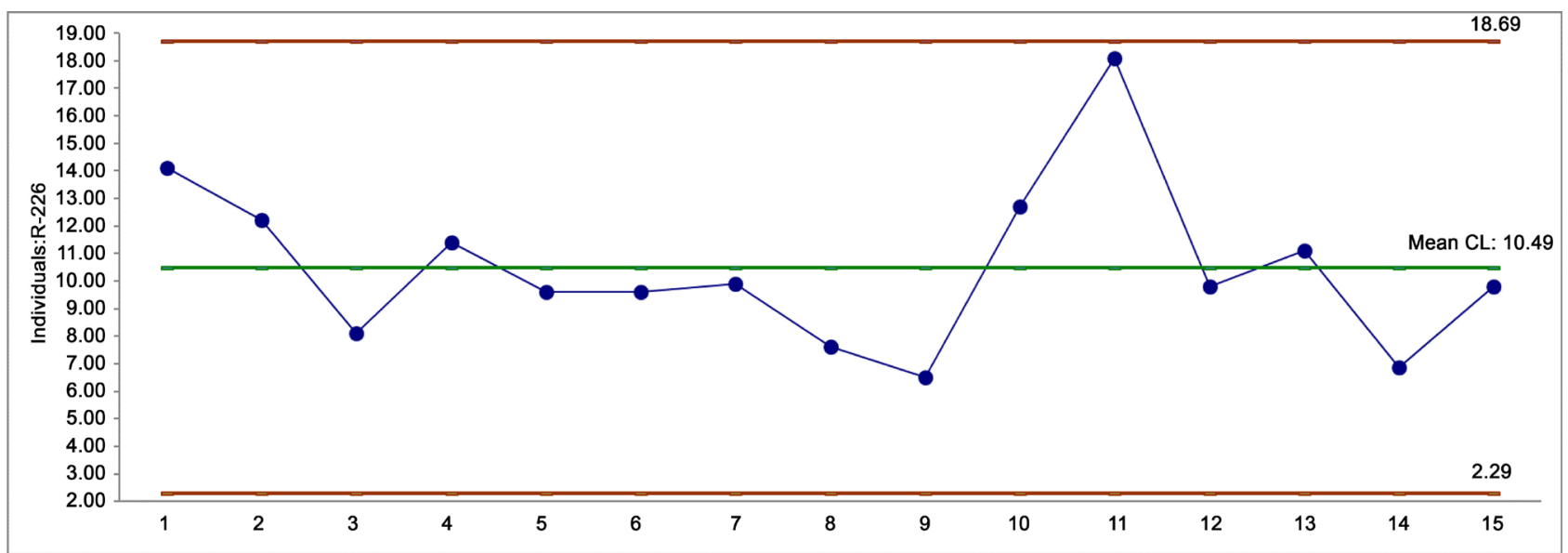

Figure 6. The Shawhart confidence limits of K-40.

while, this study, showed the range of Th-232 was 4.9 to $12.4 \mathrm{~Bq} / \mathrm{kg}$. So, it can be stated that the study adhesives were within the worldwide range. K-40, in Turhan study, was ranging 21 to $816 \mathrm{~Bq} / \mathrm{kg}$ whereas in this study was 0 to $183 \mathrm{~Bq} / \mathrm{kg}$. Therefore, the natural radioactivity in adhesives, by this study, were less than the 
worldwide values.

\section{Correlations of Heavy Metals and Radioactivity in Adhesive Materials}

This section deals with previous unpublished data of heavy metals in adhesive materials and their correlation with radioactivity. It is a step to explore the relationship between them in form of matrix correlations and Mood's test (Monte Carlo).

Using Mood's Median Test, the obtained results showed there was different in the medians of the data as calculated in Table 5 and can be shown in Figure 7. Thus, the obtained results of heavy metals levels and natural radioactivity may be treated as non-parametric data.

Table 6 and Table 7 show the calculations of correlations of the studied adhesive materials between selected heavy metals and natural radioactivity.

$\mathrm{K}-40$ was positively correlated with $\mathrm{Ga}, \mathrm{As}, \mathrm{Mo}$, and $\mathrm{Cd}$. Th-232 was also correlated with $\mathrm{Ga}$, As, and $\mathrm{Cd}$.

Using Mood's Median Test, the obtained results showed there was different in the medians of the data as calculated in Table 5 and can be shown in Figure 5 . Thus, the obtained results of heavy metals levels and natural radioactivity may be treated as non-parametric data.

\section{Conclusions}

In Figure 8 and Table 8, the obtained results of Radium equivalent radiation hazard index showed that data were located below the max permissible limit of $370 \mathrm{~Bq} / \mathrm{kg}$. Therefore, the radiation hazard index of $R a_{e q}$ indicated the analysed adhesive material were not contaminated with NORM.

Table 5. Mood's median test for adhesive materials.

Test Information

H0: Median $1=$ Median $2=\ldots=$ Median $\mathrm{k}$

Ha: At least one pair Median i Median j

\begin{tabular}{|c|c|c|c|c|c|c|c|c|c|c|c|c|c|c|}
\hline Results: & $\mathrm{Cr}$ & $\mathrm{Zn}$ & $\mathrm{Ga}$ & As & $\mathrm{Sr}$ & Mo & $\mathrm{Cd}$ & $\mathrm{Ba}$ & $\mathrm{Pb}$ & $\mathrm{Bi}$ & $\mathrm{U} 238$ & $\mathrm{~K}-40$ & $\mathrm{Ra}-226$ & Th-232 \\
\hline Count $(\mathrm{N} \leq$ Overall Median $)$ & 2 & 5 & 14 & 15 & 0 & 14 & 15 & 0 & 12 & 11 & 15 & 2 & 0 & 0 \\
\hline Count $(\mathrm{N}>$ Overall Median $)$ & 13 & 10 & 1 & 0 & 15 & 1 & 0 & 15 & 3 & 4 & 0 & 13 & 15 & 15 \\
\hline Median & 5.70 & 3.87 & 1.38 & 0.74 & 32.75 & 1.17 & 0.21 & 23.54 & 1.97 & 0.18 & 0.68 & 32.00 & 9.80 & 6.40 \\
\hline UC Median (2-sided, 95\%) & 8.98 & 4.39 & 1.77 & 0.97 & 47.45 & 1.55 & 0.27 & 31.29 & 3.26 & 4.11 & 0.83 & 62.11 & 11.90 & 7.60 \\
\hline LC Median (2-sided, 95\%) & 4.38 & 3.44 & 1.09 & 0.66 & 24.33 & 0.82 & 0.13 & 10.82 & 1.50 & 0.03 & 0.55 & 12.82 & 8.66 & 5.45 \\
\hline Overall Median & 3.626 & & & & & & & & & & & & & \\
\hline Chi-Square & 154 & & & & & & & & & & & & & \\
\hline DF & 13 & & & & & & & & & & & & & \\
\hline P-Value (2-sided) & 0.0000 & & & & & & & & & & & & & \\
\hline
\end{tabular}




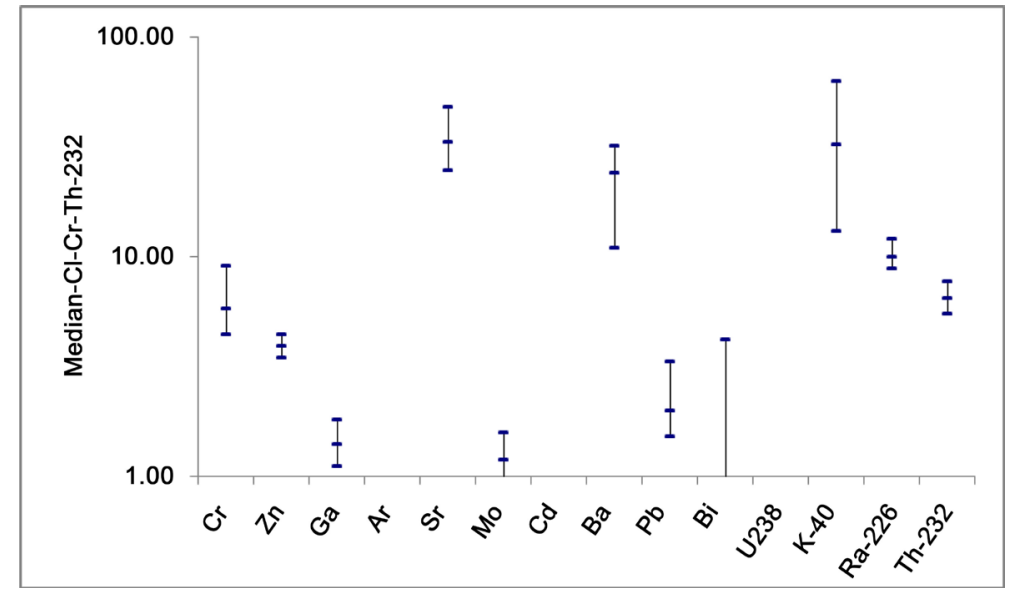

Figure 7. Medians (log scale) of adhesive materials for Mood's median test.

Table 6. Correlation calculations between chemical and radiation measurements using Pearson Methods for adhesive materials.

\begin{tabular}{|c|c|c|c|c|c|c|c|c|c|c|c|c|c|c|}
\hline Pearson Correlations & $\mathrm{Cr}$ & $\mathrm{Zn}$ & $\mathrm{Ga}$ & As & $\mathrm{Sr}$ & Mo & $\mathrm{Cd}$ & $\mathrm{Ba}$ & $\mathrm{Pb}$ & $\mathrm{Bi}$ & $\mathrm{K}-40$ & $\mathrm{Ra}-226$ & Th-232 & U-238 \\
\hline $\mathrm{Cr}$ & 1 & 0.0184 & 0.1952 & -0.2415 & 0.7283 & -0.1013 & -0.0168 & 0.0416 & 0.3076 & 0.3129 & 0.1172 & -0.1953 & -0.1649 & -0.0044 \\
\hline $\mathrm{Zn}$ & & 1 & 0.4322 & 0.5571 & -0.1850 & 0.5997 & 0.5145 & 0.4254 & 0.1814 & 0.2489 & 0.4857 & 0.1627 & 0.2882 & -0.1536 \\
\hline $\mathrm{Ga}$ & & & 1 & 0.5967 & 0.2276 & 0.2831 & 0.6114 & 0.8990 & 0.5221 & 0.0732 & 0.5241 & -0.0345 & 0.5740 & 0.0352 \\
\hline As & & & & 1 & -0.3862 & 0.7136 & 0.7798 & 0.5659 & -0.1353 & 0.1225 & 0.6512 & 0.0787 & 0.6002 & -0.3315 \\
\hline $\mathrm{Sr}$ & & & & & 1 & -0.2175 & -0.3477 & 0.0303 & 0.6765 & 0.1157 & 0.1258 & -0.3674 & -0.0532 & 0.5838 \\
\hline Mo & & & & & & 1 & 0.5305 & 0.1477 & -0.1616 & 0.6229 & 0.7677 & 0.0832 & 0.2417 & -0.2492 \\
\hline $\mathrm{Cd}$ & & & & & & & 1 & 0.6037 & -0.1533 & 0.0450 & 0.6774 & 0.0753 & 0.5058 & -0.3984 \\
\hline $\mathrm{Ba}$ & & & & & & & & 1 & 0.3562 & -0.0944 & 0.3624 & 0.0347 & 0.5495 & -0.0914 \\
\hline $\mathrm{Pb}$ & & & & & & & & & 1 & -0.0304 & 0.0455 & -0.3514 & 0.3123 & 0.6187 \\
\hline $\mathrm{Bi}$ & & & & & & & & & & 1 & 0.3317 & -0.0142 & -0.1309 & -0.3190 \\
\hline U 238 & & & & & & & & & & & 1 & -0.1030 & 0.4035 & 0.0166 \\
\hline $\mathrm{K}-40$ & & & & & & & & & & & & 1 & -0.1287 & -0.2703 \\
\hline $\mathrm{Ra}-226$ & & & & & & & & & & & & & 1 & 0.0320 \\
\hline Th-232 & & & & & & & & & & & & & & 1 \\
\hline Pearson Probabilities & $\mathrm{Cr}$ & $\mathrm{Zn}$ & $\mathrm{Ga}$ & As & $\mathrm{Sr}$ & Mo & $\mathrm{Cd}$ & $\mathrm{Ba}$ & $\mathrm{Pb}$ & $\mathrm{Bi}$ & $\mathrm{K}-40$ & $\mathrm{Ra}-226$ & Th-232 & $\mathrm{U}-238$ \\
\hline $\mathrm{Cr}$ & & 0.9481 & 0.4856 & 0.3859 & 0.0021 & 0.7196 & 0.9526 & 0.8830 & 0.2648 & 0.2562 & 0.6775 & 0.4855 & 0.5570 & 0.9875 \\
\hline $\mathrm{Zn}$ & & & 0.1076 & 0.0310 & 0.5093 & 0.0181 & 0.0497 & 0.1139 & 0.5177 & 0.3711 & 0.0664 & 0.5623 & 0.2976 & 0.5848 \\
\hline $\mathrm{Ga}$ & & & & 0.0189 & 0.4145 & 0.3065 & 0.0155 & 0.0000 & 0.0459 & 0.7955 & 0.0449 & 0.9029 & 0.0252 & 0.9010 \\
\hline As & & & & & 0.1551 & 0.0028 & 0.0006 & 0.0279 & 0.6307 & 0.6636 & 0.0086 & 0.7804 & 0.0180 & 0.2274 \\
\hline $\mathrm{Sr}$ & & & & & & 0.4363 & 0.2042 & 0.9146 & 0.0056 & 0.6813 & 0.6551 & 0.1779 & 0.8506 & 0.0223 \\
\hline Mo & & & & & & & 0.0419 & 0.5993 & 0.5649 & 0.0131 & 0.0008 & 0.7682 & 0.3856 & 0.3704 \\
\hline $\mathrm{Cd}$ & & & & & & & & 0.0172 & 0.5854 & 0.8734 & 0.0055 & 0.7897 & 0.0544 & 0.1414 \\
\hline $\mathrm{Ba}$ & & & & & & & & & 0.1925 & 0.7379 & 0.1844 & 0.9024 & 0.0339 & 0.7458 \\
\hline $\mathrm{Pb}$ & & & & & & & & & & 0.9144 & 0.8721 & 0.1990 & 0.2571 & 0.0139 \\
\hline $\mathrm{Bi}$ & & & & & & & & & & & 0.2272 & 0.9599 & 0.6419 & 0.2465 \\
\hline U-238 & & & & & & & & & & & & 0.7148 & 0.1358 & 0.9533 \\
\hline $\mathrm{K}-40$ & & & & & & & & & & & & & 0.6477 & 0.3299 \\
\hline $\mathrm{Ra}-226$ & & & & & & & & & & & & & & 0.9100 \\
\hline Th-232 & & & & & & & & & & & & & & \\
\hline
\end{tabular}


Table 7. Correlation calculations between chemical and radiation measurements using spearman Rank Correlations Methods for adhesive materials.

\begin{tabular}{|c|c|c|c|c|c|c|c|c|c|c|c|c|c|c|}
\hline $\begin{array}{l}\text { Spearman Rank } \\
\text { Correlations }\end{array}$ & $\mathrm{Cr}$ & $\mathrm{Zn}$ & $\mathrm{Ga}$ & As & $\mathrm{Sr}$ & Mo & $\mathrm{Cd}$ & $\mathrm{Ba}$ & $\mathrm{Pb}$ & $\mathrm{Bi}$ & $\mathrm{K}-40$ & $\mathrm{Ra}-226$ & Th-232 & $\mathrm{U}-238$ \\
\hline $\mathrm{Cr}$ & 1 & -0.0750 & 0.3893 & -0.2536 & 0.7571 & -0.0679 & -0.1179 & 0.3000 & 0.5036 & 0.3429 & 0.0107 & -0.2359 & -0.2111 & 0.1735 \\
\hline $\mathrm{Zn}$ & & 1 & 0.3107 & 0.4179 & -0.2786 & 0.5000 & 0.3679 & 0.2321 & 0.0321 & 0.2464 & 0.3929 & 0.4433 & -0.0233 & -0.2147 \\
\hline $\mathrm{Ga}$ & & & 1 & 0.3036 & 0.3679 & 0.5393 & 0.2714 & 0.7286 & 0.5821 & 0.5464 & 0.5857 & 0.1233 & 0.1771 & 0.0429 \\
\hline As & & & & 1 & -0.5500 & 0.6357 & 0.4143 & -0.0679 & -0.3500 & 0.2464 & 0.4750 & 0.4629 & 0.0930 & -0.3041 \\
\hline $\mathrm{Sr}$ & & & & & 1 & -0.1857 & -0.2857 & 0.3607 & 0.7893 & 0.2143 & 0.0821 & -0.5612 & 0.0984 & 0.5295 \\
\hline Mo & & & & & & 1 & 0.6357 & 0.1679 & -0.0464 & 0.7071 & 0.7857 & 0.4486 & 0.2630 & -0.2558 \\
\hline $\mathrm{Cd}$ & & & & & & & 1 & -0.1143 & -0.1429 & 0.2393 & 0.6607 & 0.1305 & 0.1020 & -0.1843 \\
\hline $\mathrm{Ba}$ & & & & & & & & 1 & 0.5786 & 0.1286 & 0.1357 & 0.1055 & 0.0501 & 0.0555 \\
\hline $\mathrm{Pb}$ & & & & & & & & & 1 & 0.1429 & 0.1250 & -0.4772 & 0.4168 & 0.3345 \\
\hline $\mathrm{Bi}$ & & & & & & & & & & 1 & 0.5107 & 0.3092 & 0.0519 & -0.2075 \\
\hline U 238 & & & & & & & & & & & 1 & 0.0268 & 0.3059 & 0.1342 \\
\hline $\mathrm{K}-40$ & & & & & & & & & & & & 1 & -0.2677 & -0.3715 \\
\hline $\mathrm{Ra}-226$ & & & & & & & & & & & & & 1 & 0.0995 \\
\hline Th-232 & & & & & & & & & & & & & & 1 \\
\hline $\begin{array}{l}\text { Spearman Rank } \\
\text { Probabilities }\end{array}$ & $\mathrm{Cr}$ & $\mathrm{Zn}$ & $\mathrm{Ga}$ & As & $\mathrm{Sr}$ & Mo & $\mathrm{Cd}$ & $\mathrm{Ba}$ & $\mathrm{Pb}$ & $\mathrm{Bi}$ & $\mathrm{K}-40$ & $\mathrm{Ra}-226$ & Th-232 & U-238 \\
\hline $\mathrm{Cr}$ & & 0.7905 & 0.1515 & 0.3618 & 0.0011 & 0.8101 & 0.6757 & 0.2773 & 0.0557 & 0.2109 & 0.9698 & 0.3973 & 0.4501 & 0.5363 \\
\hline $\mathrm{Zn}$ & & & 0.2597 & 0.1212 & 0.3147 & 0.0577 & 0.1773 & 0.4051 & 0.9095 & 0.3760 & 0.1475 & 0.0980 & 0.9344 & 0.4423 \\
\hline $\mathrm{Ga}$ & & & & 0.2714 & 0.1773 & 0.0380 & 0.3278 & 0.0021 & 0.0228 & 0.0351 & 0.0218 & 0.6615 & 0.5278 & 0.8792 \\
\hline As & & & & & 0.0337 & 0.0109 & 0.1247 & 0.8101 & 0.2009 & 0.3760 & 0.0736 & 0.0823 & 0.7416 & 0.2705 \\
\hline $\mathrm{Sr}$ & & & & & & 0.5075 & 0.3019 & 0.1866 & 0.0005 & 0.4431 & 0.7710 & 0.0295 & 0.7272 & 0.0424 \\
\hline Mo & & & & & & & 0.0109 & 0.5499 & 0.8695 & 0.0032 & 0.0005 & 0.0935 & 0.3437 & 0.3574 \\
\hline $\mathrm{Cd}$ & & & & & & & & 0.6851 & 0.6115 & 0.3904 & 0.0073 & 0.6430 & 0.7176 & 0.5109 \\
\hline $\mathrm{Ba}$ & & & & & & & & & 0.0238 & 0.6479 & 0.6296 & 0.7084 & 0.8593 & 0.8444 \\
\hline $\mathrm{Pb}$ & & & & & & & & & & 0.6115 & 0.6571 & 0.0721 & 0.1222 & 0.2230 \\
\hline $\mathrm{Bi}$ & & & & & & & & & & & 0.0517 & 0.2621 & 0.8543 & 0.4580 \\
\hline U 238 & & & & & & & & & & & & 0.9244 & 0.2675 & 0.6336 \\
\hline $\mathrm{K}-40$ & & & & & & & & & & & & & 0.3348 & 0.1727 \\
\hline $\mathrm{Ra}-226$ & & & & & & & & & & & & & & 0.7243 \\
\hline Th-232 & & & & & & & & & & & & & & \\
\hline
\end{tabular}

Figure 9 shows the obtained results of external hazard values where all the reported data are located below 0.09 . The average external radiation hazard was much more below the permissible limit of one mSv/yr. Thus, it can be stated that adhesive materials were free of natural radioactivity in term of external radiation hazard. 


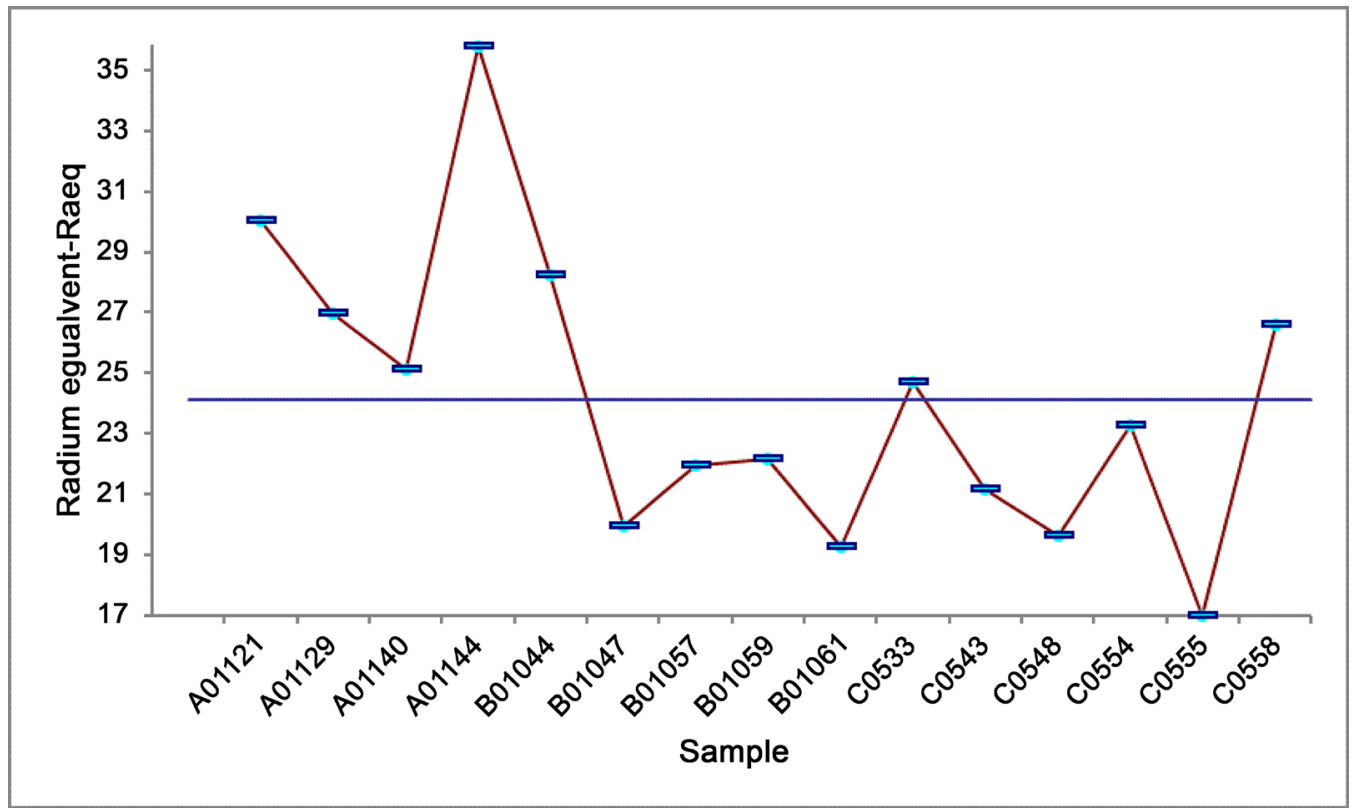

Figure 8. Radium equivalent values of the adhesive materials.

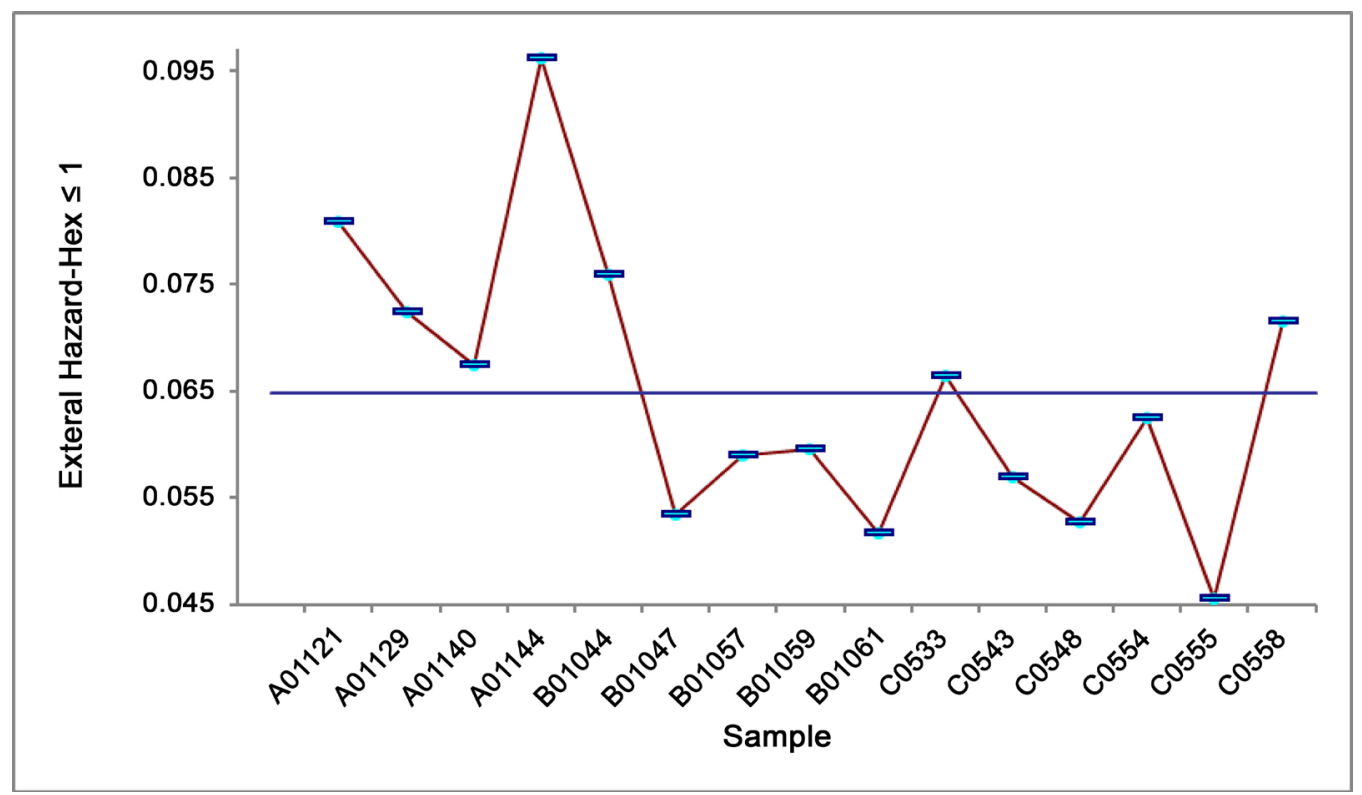

Figure 9. External Hazard values of the adhesive materials.

Similarly, the internal radiation hazard was computed as demonstrated in Figure 10. All the reported data of internal radiation hazard were in range of less than 0.1 whereas the max allowable limit is fixed by one.

The last radiation hazard index used in this study was annual effective dose. This index is the most important radiation index in any radiation risk assessment. Figure 11 shows the average valued of annual effective dose was less than 0.07 while the fixed value of this index is one $\mathrm{mSv} / \mathrm{yr}$.

Turhan, eref et al. [25] reported natural radioactivity in adhesive materials. In their study, U-238 activities were 7.3 to $69.4 \mathrm{~Bq} / \mathrm{kg}$ whereas this study showed 
the ranges were 0 to $17 \mathrm{~Bq} / \mathrm{kg}$. Thus, the study adhesives were located within the worldwide ranges. In Turhan study, Th-232 activity was 2 to $57 \mathrm{~Bq} / \mathrm{kg}$ in adhesives while, this study, showed the range of Th-232 was 4.9 to $12.4 \mathrm{~Bq} / \mathrm{kg}$. So, it can be stated that the study adhesives were within the worldwide range. K-40, in Turhan study, was ranging 21 to $816 \mathrm{~Bq} / \mathrm{kg}$ whereas in this study was 0 to 183 $\mathrm{Bq} / \mathrm{kg}$. Therefore, the natural radioactivity in adhesives, by this study, were less than the worldwide demonstrated in Table 9. It can be stated that the study

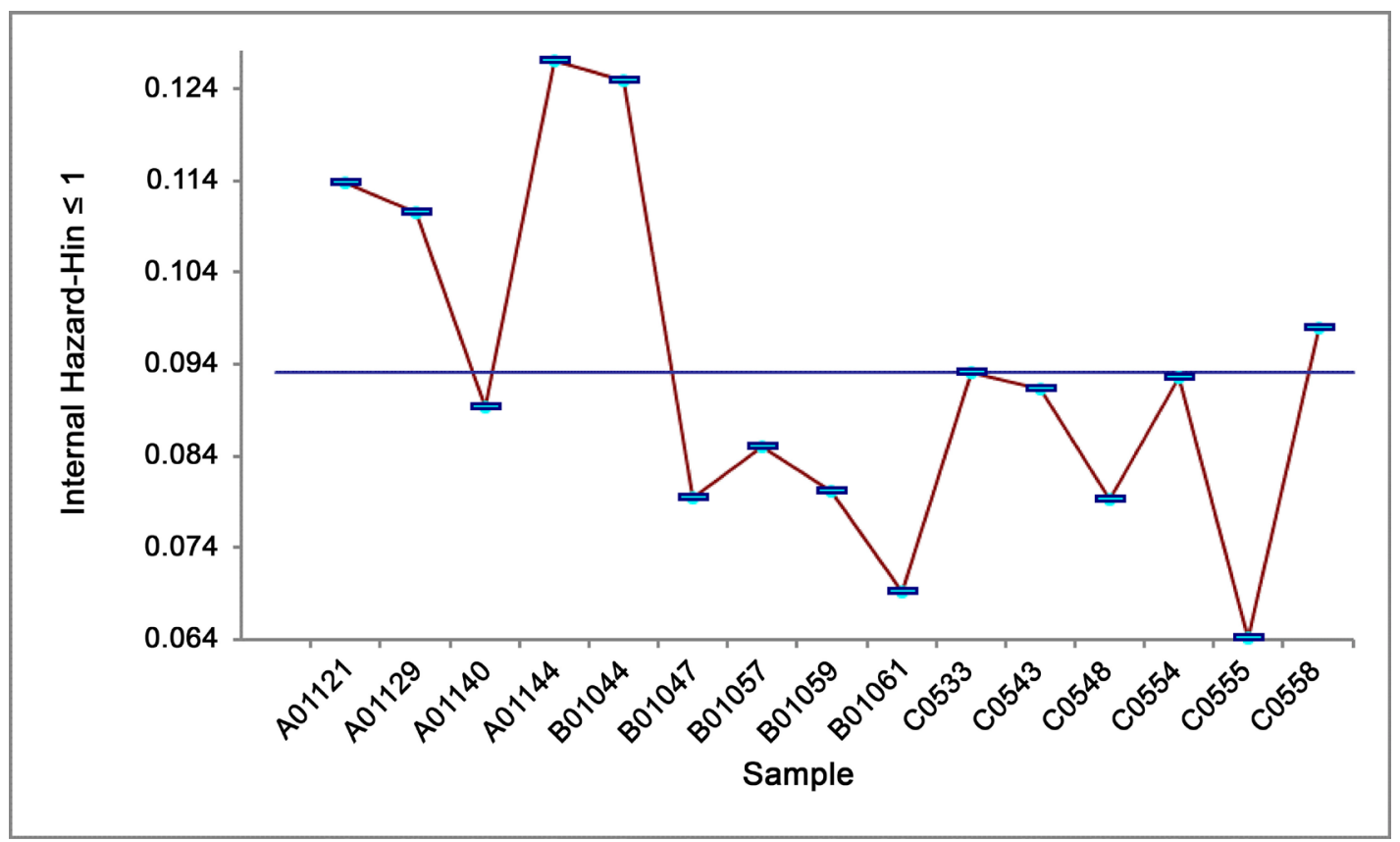

Figure 10. Internal Hazard values of the adhesive materials.

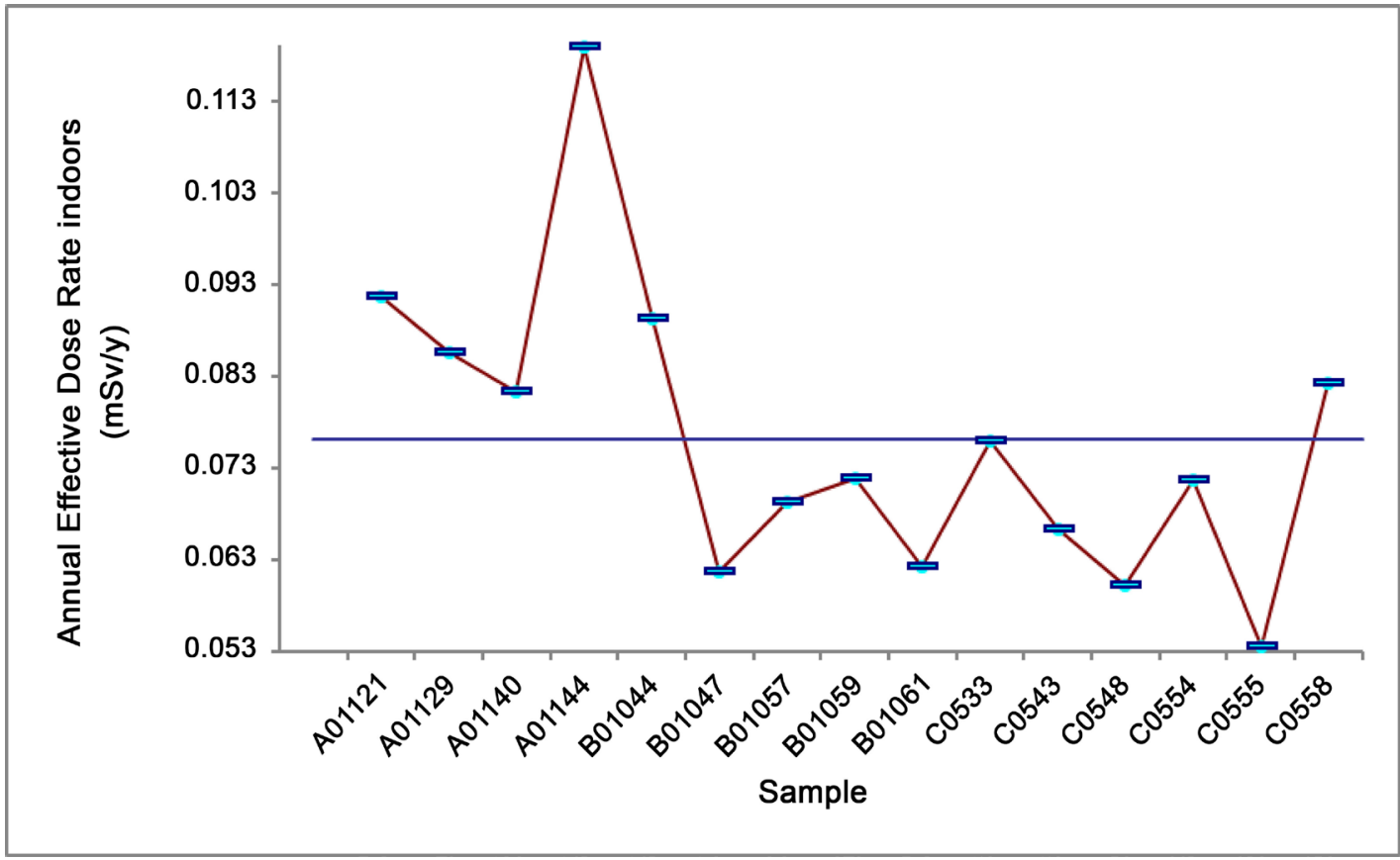

Figure 11. Radium equivalent values of the adhesive materials. 
Table 8. Radiation calculations for Porcelain materials.

\begin{tabular}{|c|c|c|c|c|c|c|c|c|c|c|c|}
\hline Sample code & $\begin{array}{l}\mathrm{K}-40 \\
\mathrm{~Bq} \backslash \mathrm{Kg}\end{array}$ & $\begin{array}{c}\text { Ra-226 } \\
\mathrm{Bq} \backslash \mathrm{Kg}\end{array}$ & $\begin{array}{c}\text { Th-232 } \\
\mathrm{Bq} \backslash \mathrm{Kg}\end{array}$ & $\begin{array}{l}\mathrm{U}-238 \\
\mathrm{~Bq} \backslash \mathrm{Kg}\end{array}$ & $\mathrm{Ra}$ eq & $H_{e x} \leq 1$ & $H_{\text {in }} \leq 1$ & $\begin{array}{c}\alpha \\
\text { Concentration }\end{array}$ & $\begin{array}{c}a \\
\text { index }\end{array}$ & $\begin{array}{l}\text { Outdoor } \\
\text { dose }\end{array}$ & $\begin{array}{c}\text { Annual } \\
\text { Effective } \\
\text { Dose }(\mathrm{mSv} / \mathrm{y})\end{array}$ \\
\hline A10118 & 904 & 86 & 100 & 71.3 & 299 & 0.81 & 1.04 & 1.09 & 0.43 & 140 & 0.96 \\
\hline A01119 & 567 & 62.4 & 67 & 61 & 202 & 0.55 & 0.71 & 0.73 & 0.31 & 94 & 0.65 \\
\hline A01125 & 323 & 46 & 45 & 0 & 135 & 0.37 & 0.49 & 0.49 & 0.23 & 63 & 0.43 \\
\hline B01034 & 811 & 86.8 & 101.1 & 100.3 & 294 & 0.79 & 1.03 & 1.07 & 0.43 & 137 & 0.94 \\
\hline B01037 & 42.5 & 0.1 & 0.1 & 0 & 3.52 & 0.01 & 0.01 & 0.02 & 0.00 & 2 & 0.01 \\
\hline B01040 & 514 & 43.2 & 77.3 & 53.6 & 193 & 0.52 & 0.64 & 0.70 & 0.22 & 89 & 0.61 \\
\hline A01131 & 226.7 & 12.9 & 8.8 & 6.06 & 42.94 & 0.12 & 0.15 & 0.16 & 0.06 & 21 & 0.14 \\
\hline A0133 & 621.7 & 48.4 & 51.3 & 55.4 & 170 & 0.46 & 0.59 & 0.63 & 0.24 & 80 & 0.55 \\
\hline A0134 & 914.3 & 55.00 & 57.40 & 57.30 & 207 & 0.56 & 0.71 & 0.78 & 0.28 & 99 & 0.68 \\
\hline A01136 & 938.5 & 57 & 58 & 37.9 & 212 & 0.57 & 0.73 & 0.79 & 0.29 & 102 & 0.70 \\
\hline A01139 & 678 & 44 & 49.0 & 40 & 166 & 0.45 & 0.57 & 0.62 & 0.22 & 79 & 0.54 \\
\hline A01141 & 618 & 84 & 47.7 & 60 & 200 & 0.54 & 0.77 & 1 & 0.42 & 94 & 0.65 \\
\hline B01048 & 831 & 57 & 55.8 & 45 & 200 & 0.54 & 0.69 & 0.74 & 0.28 & 95 & 0.66 \\
\hline B01050 & 352 & 32 & 27.6 & 38 & 98 & 0.27 & 0.35 & 0.36 & 0.16 & 47 & 0.32 \\
\hline $\mathrm{C} 0540$ & 682 & 72 & 88.9 & 76 & 252 & 0.68 & 0.87 & 0.91 & 0.36 & 117 & 0.80 \\
\hline $\mathrm{C} 0545$ & 497 & 135 & 126.4 & 116 & 354 & 0.96 & 1.32 & 1.25 & 0.68 & 162 & 1.11 \\
\hline $\mathrm{C} 0547$ & 485 & 39 & 42.8 & 37 & 137 & 0.37 & 0.47 & 0.50 & 0.19 & 65 & 0.44 \\
\hline C0549 & 787 & 123 & 93.9 & 92 & 318 & 0.86 & 1.19 & 1.14 & 0.62 & 148 & 1.02 \\
\hline $\mathrm{C} 0552$ & 321.2 & 59.1 & 57.2 & 51.2 & 166 & 0.45 & 0.61 & 0.59 & 0.30 & 76 & 0.52 \\
\hline Count & 19 & 19 & 19 & 19 & 19 & 19.00 & 19.00 & 19.00 & 19.00 & 19.0 & 19.00 \\
\hline Mean & 585 & 60 & 61 & 53 & 192 & 0.52 & 0.68 & 0.70 & 0.30 & 89.9 & 0.62 \\
\hline Stdev & 252 & 33 & 32 & 31 & 89 & 0.24 & 0.33 & 0.32 & 0.17 & 41.1 & 0.28 \\
\hline Range & 896 & 135 & 126 & 116 & 351 & 0.95 & 1.31 & 1.23 & 0.68 & 159.8 & 1.10 \\
\hline Minimum & 43 & 0 & 0 & 0 & 4 & 0.01 & 0.01 & 0.02 & 0.00 & 1.9 & 0.01 \\
\hline $25^{\text {th }}$ Percentile (Q1) & 352 & 43 & 45 & 38 & 137 & 0.37 & 0.49 & 0.50 & 0.22 & 64.6 & 0.44 \\
\hline $50^{\text {th }}$ Percentile (Median) & 618 & 57 & 57 & 54 & 200 & 0.54 & 0.69 & 0.72 & 0.28 & 94.1 & 0.65 \\
\hline $75^{\text {th }}$ Percentile (Q3) & 811 & 84 & 89 & 71 & 252 & 0.68 & 0.87 & 0.91 & 0.42 & 117.0 & 0.80 \\
\hline Maximum & 939 & 135 & 126 & 116 & 354 & 0.96 & 1.32 & 1.25 & 0.68 & 161.6 & 1.11 \\
\hline 95.0\% CI Mean & $\begin{array}{l}463 \text { to } \\
706\end{array}$ & 44 to 76 & $\begin{array}{c}45.4 \text { to } \\
76.1\end{array}$ & $\begin{array}{c}37.5 \text { to } \\
67.6\end{array}$ & $\begin{array}{l}149 \text { to } \\
235\end{array}$ & $\begin{array}{c}0.4 \text { to } \\
0.63\end{array}$ & $\begin{array}{c}0.52 \text { to } \\
0.83\end{array}$ & 0.54 to 0.85 & $\begin{array}{c}0.22 \text { to } \\
0.38\end{array}$ & $\begin{array}{c}70.1 \text { to } \\
109\end{array}$ & 0.48 to 0.75 \\
\hline $95.0 \%$ CI Sigma & $\begin{array}{c}190 \text { to } \\
373\end{array}$ & $\begin{array}{c}25 \text { to } \\
48.9\end{array}$ & 24 to 47 & $\begin{array}{c}23.5 \text { to } \\
46.14\end{array}$ & $\begin{array}{c}67 \text { to } \\
131\end{array}$ & $\begin{array}{c}0.18 \text { to } \\
0.35\end{array}$ & $\begin{array}{c}0.24 \text { to } \\
0.48\end{array}$ & 0.24 to 0.47 & $\begin{array}{c}0.12 \text { to } \\
0.24\end{array}$ & 31 to 60 & 0.21 to 0.41 \\
\hline $\begin{array}{l}\text { Anderson-Darling } \\
\text { Normality Test }\end{array}$ & 0.24 & 0.45 & 0.35 & 0.36 & 0.32 & 0.32 & 0.28 & 0.27 & 0.45 & 0.27 & 0.27 \\
\hline P-Value (A-D Test) & 0.75 & 0.25 & 0.44 & 0.42 & 0.51 & 0.51 & 0.60 & 0.64 & 0.25 & 0.63 & 0.63 \\
\hline Skewness & -0.42 & 0.61 & 0.11 & 0.09 & -0.22 & -0.22 & -0.03 & -0.31 & 0.61 & -0.29 & -0.29 \\
\hline P-Value (Skewness) & 0.41 & 0.23 & 0.83 & 0.86 & 0.66 & 0.66 & 0.96 & 0.53 & 0.23 & 0.56 & 0.56 \\
\hline Kurtosis & -0.48 & 0.80 & 0.06 & 0.06 & 0.17 & 0.17 & 0.30 & 0.14 & 0.80 & 0.15 & 0.15 \\
\hline P-Value (Kurtosis) & 0.72 & 0.34 & 0.77 & 0.76 & 0.68 & 0.68 & 0.60 & 0.71 & 0.34 & 0.70 & 0.70 \\
\hline
\end{tabular}


Table 9. Comparison of activity concentrations and radium equivalent activities in tiles in the world [12].

\begin{tabular}{cccccccccc}
\hline \multirow{2}{*}{ Coutnry } & \multirow{2}{*}{ Raeq } & Dose & \multicolumn{2}{c}{ Annual effective } & \multirow{2}{*}{ EAD } & I & Hin & Hex \\
\cline { 5 - 6 } & & & indoor & outdoor & & & & \\
\hline China & 306.40 & 141.92 & 0.70 & 0.17 & 1.33 & 1.11 & 1.13 & 0.83 \\
China & 332.76 & 152.16 & 0.75 & 0.19 & 1.41 & 1.20 & 1.16 & 0.90 \\
Spain & 171.49 & 80.69 & 0.40 & 0.10 & 0.75 & 0.64 & 0.59 & 0.46 \\
U.A.E & 179.77 & 81.20 & 0.40 & 0.10 & 0.75 & 0.65 & 0.57 & 0.49 \\
Italy & 243.06 & 108.03 & 0.53 & 0.13 & 1.01 & 0.84 & 0.93 & 0.66 \\
Ave. & 246.69 & 112.80 & 0.55 & 0.14 & 1.05 & 0.89 & 0.88 & 0.67 \\
Min. & 171.49 & 80.69 & 0.40 & 0.10 & 0.75 & 0.64 & 0.57 & 0.46 \\
Max. & 332.76 & 152.16 & 0.75 & 0.19 & 1.41 & 1.20 & 1.16 & 0.90 \\
\hline
\end{tabular}

adhesive building materials were safe to be used in construction building materials in term of natural radioactivity.

\section{References}

[1] United Nations Scientific Committee on the Effects of Atomic Radiation (2000) Sources and Effects of Ionizing Radiation: Sources. United Nations Publications.

[2] Wilson, W.F. (1994) NORM: A Guide to Naturally Occurring Radioactive Material. Pennwell Corporation.

[3] Watson, S., et al. (2005) Ionising Radiation Exposure of the UK Population: 2005 Review. Radiation Protection Division, Health Protection Agency, HPA-RPD-001.

[4] Ortiz, J., et al. (2007) Radioactivity Reference Levels in Ceramics Tiles as Building Materials for Different Countries.

[5] Lust, M. and Realo, E. (2012) Assessment of Natural Radiation Exposure from Building Materials in Estonia. Proceedings of the Estonian Academy of Sciences, 61, 107-112. https://doi.org/10.3176/proc.2012.2.03

[6] Etokov, A. and Palakov, L. (2013) Assessment of Natural Radioactivity Levels of Cements and Cement Composites in the Slovak Republic. International Journal of Environmental Research and Public Health, 10, 7165-7179. https://doi.org/10.3390/ijerph10127165

[7] Singh, C., et al. (2004) Energy and Chemical Composition Dependence of Mass Attenuation Coefficients of Building Materials. Annals of Nuclear Energy, 31, 1199-1205. https://doi.org/10.1016/j.anucene.2004.02.002

[8] Alharbi, W. and Al Zahrani, J. (2012) Assessment of Natural Radioactivity Levels and Associated Radiation Hazards of Building Materials Used in Saudi Arabia. The Journal of American Science, 8, 651-656.

[9] Al-Sulaiti, H., et al. (2017) An Assessment of the Natural Radioactivity Distribution and Radiation Hazard in Soil Samples from Qatar using High-Resolution Gamma-ray Spectrometry. Radiation Physics and Chemistry, 40, 132-136. https://doi.org/10.1016/j.radphyschem.2017.05.001

[10] Priharti, W., et al. (2016) Assessment of Radiation Hazard Indices Arising from Natural Radionuclides Content of Powdered Milk in Malaysia. Journal of Radioanalytical and Nuclear Chemistry, 307, 297-303. 
https://doi.org/10.1007/s10967-015-4172-8

[11] Al-Hamarneh, I.F. and Awadallah, M.I. (2009) Soil Radioactivity Levels and Radiation Hazard Assessment in the Highlands of Northern Jordan. Radiation Measurements, 44, 102-110. https://doi.org/10.1016/j.radmeas.2008.11.005

[12] Sanusi, M.S.M., et al. (2016) Investigation of Geological and Soil Influence on Natural Gamma Radiation Exposure and Assessment of Radiation Hazards in Western Region, Peninsular Malaysia. Environmental Earth Sciences, 75, 485. https://doi.org/10.1007/s12665-016-5290-5

[13] Bikit, I., et al. (2006) Measurement of Danube Sediment Radioactivity in Serbia and Montenegro Using Gamma Ray Spectrometry. Radiation Measurements, 41, 477 481. https://doi.org/10.1016/j.radmeas.2005.10.001

[14] Khater, A.E. and Al-Sewaidan, H. (2008) Radiation Exposure Due to Agricultural Uses of Phosphate Fertilizers. Radiation Measurements, 43, 1402-1407.

https://doi.org/10.1016/j.radmeas.2008.04.084

[15] Chang, B., et al. (2008) Nationwide Survey on the Natural Radionuclides in Industrial Raw Minerals in South Korea. Journal of Environmental Radioactivity, 99, 455-460. https://doi.org/10.1016/j.jenvrad.2007.08.020

[16] Hameed, B.S., et al. (2016) Study the Concentration of Naturally Occurring Radioactive Materials in the Samples of Rice and Salt in Baghdad Governorate. Journal of Al-Nahrain University, Science, 19, 104-109. https://doi.org/10.22401/JNUS.19.1.13

[17] Jibiri, N., et al. (2007) Estimation of Annual Effective Dose Due to Natural Radioactive Elements in Ingestion of Foodstuffs in Tin Mining Area of Jos-Plateau, Nigeria. Journal of Environmental Radioactivity, 94, 31-40. https://doi.org/10.1016/j.jenvrad.2006.12.011

[18] Hilal, M., et al. (2014) Evaluation of Radiation Hazard Potential of TENORM Waste from Oil and Natural Gas Production. Journal of Environmental Radioactivity, 136, 121-126. https://doi.org/10.1016/j.jenvrad.2014.05.016

[19] Krieger, R. (1981) Radioactivity of Construction Materials. Betonwerk Fertigteil-Technik, 47, 468.

[20] Lu, X., et al. (2014) Determination of Natural Radioactivity and Associated Radiation Hazard in Building Materials Used in Weinan, China. Radiation Physics and Chemistry, 99, 62-67. https://doi.org/10.1016/j.radphyschem.2014.02.021

[21] Ravisankar, R., et al. (2014) Spatial Distribution of Gamma Radioactivity Levels and Radiological Hazard Indices in the East Coastal Sediments of Tamilnadu, India with Statistical Approach. Radiation Physics and Chemistry, 103, 89-98. https://doi.org/10.1016/j.radphyschem.2014.05.037

[22] Alshammari, H., et al. (2017) The Experimental and Sim-Ulation Risk Assessment of Radioactivity in Marble Building Materials Used in Saudi Arabia. Journal of Fundamental and Applied Sciences, 9, 1341-1348.

[23] Hassan, N.M., et al. (2017) Assessment of Radiation Hazards Due to Exposure to Radio Nuclides in Marble and Ceramic Commonly Used as Decorative Building Materials in Egypt. Indoor and Built Environment, 26, 317-326. https://doi.org/10.1177/1420326X15606507

[24] Sanusi, M., et al. (2017) Assessment of Impact of Urbanization on Background Radiation Exposure and Human Health Risk Estimation in Kuala Lumpur, Malaysia. Environment International, 104, 91-101. https://doi.org/10.1016/j.envint.2017.01.009

[25] Turhan, et al. (2008) Measurement of the Natural Radioactivity. 